\title{
Sports Fans' Behavior on Twitter: A Big Data Analysis of Sentiments in the 2018 World Cup Final
}

\author{
Ahmet ATALAY \\ ${ }^{1}$ Ardahan University, School of Physical Education and Sport, Ardahan.
}

Original Article

Received: 06.03.2021
Accepted: 24.04.2021
DOI: $10.25307 /$ jssr.892337

Online Publishing: 30.06 .2021

\begin{abstract}
The purpose of the present study is to determine the words that came to the forefront of social media posts by fans for the 2018 World Cup Final, the most frequently used expressions, and the emotional tendencies of the fans. For this purpose, 56,877 tweets written in English on Twitter on the 2018 World Cup Final were extracted by the "R-Project" software and analyzed. According to the analysis results, it was concluded that a total of twenty positive statements were used with the highest frequency by fans, and it was also determined that the positive emotional trend was dominant compared to the negative trend, irrespective of what the result of the match was. In conclusion, it may be claimed that the perceptions and reactions of the fans regarding the World Cup Final are different from club matches at national level, and that mostly positive emotions came to the forefront.
\end{abstract}

Keywords: Sentiment analysis, Twitter, World Cup, Football, R project.

\section{Taraftarların Twitter'daki Davranışları: 2018 Dünya Kupası Final Maçı Taraftar Duygularının Büyük Veri Analizi}

$\ddot{\mathrm{O} z}$

Bu çalışmanın amacı, 2018 Dünya Kupası Final Maçında taraftar paylaşımında öne çıkan kelimeleri, bu sözlerle birlikte en sik kullanılan ifadeleri ve taraftarların duygusal eğilimlerini belirlemektir. Bu amaçla, İngilizce yazılan ve 2018 Dünya Kupası Final Maçı'nda Twitter'da paylaşılan 56.877 adet tweet, "The R-Project” adı verilen yazılım üzerinden alınarak analizleri yapıldı. Analiz sonuçlarına göre taraftar paylaşımında en yüksek sıklıkta kullanılan toplam yirmi ifadenin olumlu olduğu; final maçının sonucu ne olursa olsun, olumlu duygusal eğilimin olumsuz eğilime göre baskın olduğu da belirlendi. Sonuç olarak taraftarların Dünya Kupası Final Maçı ile ilgili algılarının ve tepkilerinin kulüpler arası ulusal düzeydeki yarışmalardan farklı olduğu ve daha çok olumlu duyguların ön plana çıktığı iddia edilebilir.

Anahtar Kelimeler: Duygu Analizi, Twitter, Dünya Kupas1, Futbol, R Proje.

\footnotetext{
*Sorumlu Yazar: Ahmet ATALAY, E-posta: ahmetatalay@ardahan.edu.tr
} 


\section{INTRODUCTION}

The year 2018 witnessed one of the festivals that are held every four years, the World Cup Football Olympics, one of humanity's biggest football festivals. The World Cup that was hosted by Russia in 2018 was carried out between 14 June and 15 July 2018. At the end of the football festival that lasted thirty days, France became the owner of the World Cup by winning against Croatia 4-2 in the final match. "Sports - especially football - are a social phenomenon with which people can reflect their reactions in a peaceful manner because this institution has eliminated differences such as religion, belief and ideology (Fişek, 1998:66)". In fact, football competitions provide fans with the opportunity to act emotionally, releasing their emotions to reveal their positive and negative reactions (Raney, 2006:315). Again, these competitions may be considered as a tool for establishing good relations among people and for bringing them together (Krilenko \& Stepchenkova, 2017). Today, this unity and communication has reached global dimensions with football stadiums and through the means of social media such as Twitter.

Thanks to social media platforms, especially Twitter, the relationship and communication among people and societies have become stronger, and are at a global level. Twitter is one of the most popular means of communication among social media platforms with its 297 million users (Yu \& Wang, 2015; Zeng \& Gerritsen, 2014). One of the fields in which the means of social media communication is widely used is football. It is possible to claim that football fans use Twitter, which is one of the most popular social media tools, intensively. Fans post their reactions and emotions on competitions via Twitter in a real-time manner (Wang, 2015; Ji \& Raney, 2014). Furthermore, after matches have been played, football fans critique the match on social media, and post their feelings and thoughts through Twitter. In addition to being a very popular means of communication, Twitter has also become a gigantic data source for academic studies, and opened the way for new studies in many fields including social sciences, politics and sport sciences (Ceron et al., 2014; Himelboim et al., 2016; Kreiss, 2016).

Today, one type of study conducted by authors is by employing Twitter data is sentiment analysis studies (Duan \& Cao, 2013; Krilenko \& Stepchenkova, 2017; Liu, 2012:42; Yu \& Wang, 2015), because, Twitter has become an important data source by providing a broad sentiment analysis platform for researchers (Pandey et al., 2017). Sentiment analysis may be defined as a method enabling researchers to determine the opinions, thoughts, and attitudes of people on products and services by obtaining their public opinions (Baudad et al., 2017; Liu, 2012:43;). In addition, it may be defined as the reporting and making sense of the large data volume on electronic platforms (Kaynar et al., 2016). In Sentiment Analysis, this making sense of the process may be carried out by employing analysis methods that are lexicon-based (Öztürk \& Ayvaz, 2018) or machine learning-based (Mackey et al., 2018). It is observed in the literature that data are analyzed with sentiment analyses studies conducted in fields such as education, politics and tourism (Aldayel \& Azmi, 2017; Deiner et al., 2017; Kim et. al., 2016; Khoo \& Johnkhan, 2018; Mostafa, 2018; Pang \& Lee, 2008; Workewych et al., 2017) and it was reported in previous studies that sentiment analysis studies may be conducted for football fans in sports sciences as well (Lucas et al., 2017; Yu \& Wang, 2015).

Although football supporters extensively use Twitter, sentiment analysis in the field of sports has not yet been adequately investigated. On point, only three studies in which the words 
"Twitter", "World Cup" and "sentiment" were used together were detected in the advanced search carried out in the Title, Abstract and Keywords sections of the Science Direct Database to examine the literature (Lucas et al., 2017; Souza et al., 2016; Yu \& Wang, 2015). It was seen that these three studies were related to the 2014 World Cup. In the present study, the sentiment analysis of the fans in the 2018 World Cup final match was performed.

It is expected that this study, which was conducted on sentiment analysis for the 2018 World Cup Final, will contribute to the relevant literature with the use of more than one sentiment glossary and the sharing of programming codes for authors, who could conduct emotion analysis studies on social media. For this reason, the purpose of this research is to determine the expressions and emotional tendencies that came to the forefront in the tweets regarding the 2018 World Cup final match. For this purpose, the answers to the following study questions were sought.

In the tweets that were written about the 2018 World Cup Final Match:

- What are the statements that come to the forefront, and what are the words that are associated with these statements?

- How is the emotional tendency that come to the forefront (Positive, Negative, Neutral)?

\section{Limitations}

This study was limited to the 56,877 tweets that were written in English and were posted on Twitter between 15-23 July 2018 regarding the 2018 World Cup final match. The reason why only English tweets were considered was that the RSentiment and Bin Liu Sentiment Glossaries used for emotion analysis are in English. In addition, as required by the Data Sharing Policy of Twitter, a maximum of 10,000 tweet data per day could be downloaded from the system. The data that were downloaded from Twitter consisted of all the tweets that contained the phrase "worldcupfinal" in their hashtags.

\section{METHODS}

\section{Research Model}

In the World Cup finals matches, it may be observed that although one team lost, the supporters of both teams had positive feelings. In this study, in which the directions and levels of these sentiments were examined, a sentiment analysis was carried out on the tweets that were shared through Twitter. For sentiment analysis, the English language tweets were scanned with the \#worldcupfinal hashtag on the days after the final match, and 56,877 tweets were found. This data were extracted with the R-Project Software, which is open-source and free, and the sentiment analysis was made again with the same software. The details on the method employed in the present study are given in the following parts.

\section{Sampling}

The sampling consisted of 56,877 English language tweets and that were posted in Twitter with the \#worldcupfinal hashtag between July 15-23, 2018. It was observed that the tweets written 
specifically for the final match of the 2018 World Cup were shared with the hashtags \#Worldcupfinal, \#Worldcupfinals, \# Worldcupfinal18 and \#Worldcupfinal2018. For this reason, all the tweets that included the \#worldcupfinal hashtag were extracted from Twitter to find the posts made with all these hashtags. The other point that was considered when downloading the data that would constitute the sampling was that the expressions used in the tweets were written in English. As the RSentiment and Bing Liu Glossaries, which would be employed during the sentiment analysis in the study, had English words, a filter was applied to ensure that the tweets were in English. Accordingly, the filtering was carried out with the lang = "en" parameter, which is provided by Twitter, during the downloading of the data, and in this way, tweets written in English about the World Cup 2018 final match constituted the sampling of the study.

When the number of sampling was determined, the situation in which the number of daily tweets about the match decreasing was taken into consideration. Subsequently, when a great decline was observed in the number tweets with the \#worldcupfinal hashtag, the data collection process for the sampling was ended, which was the $9^{\text {th }}$ day following the match. In this way, the 56,877 tweets posted between 15-23 July, 2018 constituted the sample. The graph showing the numbers of tweets by days is presented in Figure 1 below.

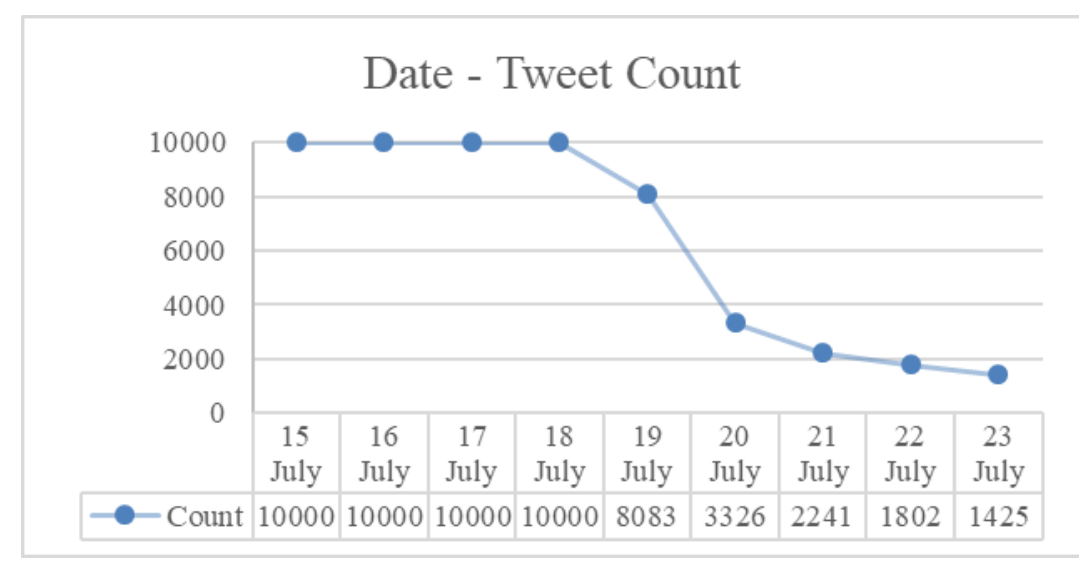

Figure 1. The distribution of the tweets that were posted on the 2018 World Cup final match according to days

When Figure 1 is examined, it is seen that over 10,000 tweets were posted during the first 4 days; and as of the 5th day, the posts decreased over time. In addition, since Twitter only allows the downloading of a maximum of 10,000 tweet data daily, the tweets that were downloaded were limited to 10,000 for the first 4 days.

\section{Data Collection Tool}

The tweet data was collected from an open source statistical computer software called ' $R$ Project'. R Project provides ease of use with many ready-made libraries for researchers and one of these libraries is 'twitteR'. In this study, all the tweet data was collected thanks to the R Project software, twitteR library and $\mathrm{R}$ programming codes written by the researchers. The $\mathrm{R}$ Project libraries and library codes used are below. 


\begin{tabular}{|lc}
\hline library(twitteR) & \# Gets the tweets on twitter \\
library(tm) & \# Creates term document matrix \\
library(wordcloud) & \# Creates word cloud \\
library(RSentiment) & \# Analysis sentiment \\
\hline
\end{tabular}

With the help of the programming codes given above, the tweets that had the "worldcupfinal" hashtag and that were written in English (maximum 10,000) were extracted and transferred to a CSV format file. When the posts on the subject matter decreased in number, all the data in the CSV files where the 9-day data were kept were collected into a single CSV file; and then the process of data cleansing was initiated for the analyses.

\section{Research Ethics}

In the scope of the protection of human and animal rights, the Journal of Sport Sciences Researches adopts the exact convenience principle of national and international ethical rules and principles. In this context, the principles of the journal and general scientific ethical rules were followed during the research process.

\section{Data Collection Process}

In the present study, the data collection process was initiated following the 2018 World Cup final match. According to its free use policy, Twitter allows the extraction of tweets made maximum one week ago. For this reason, with the help of the $\mathrm{R}$ programming codes that were written by the researchers, posts made one day ago were downloaded. To enable the researchers to conduct studies on data analysis in social media, the R-Programming codes that were employed to extract the data from Twitter are presented below.

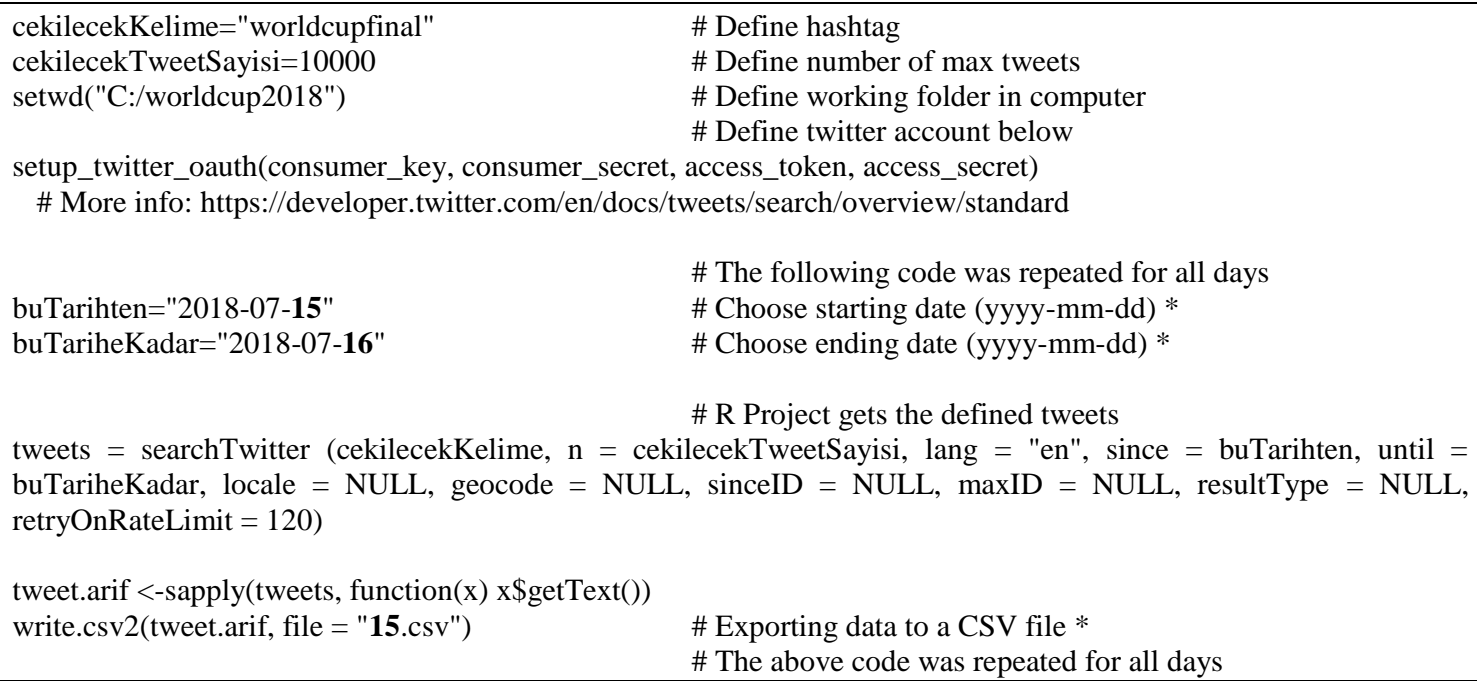

* Date in this line was changed for each day.

\section{Analysis of the Data}

A total of 56,877 tweet data were collected in 9 days were analyzed to determine the emotions, the most frequently used words, and the other words with which these words were used, that came to the forefront in posts. Firstly, the Term Document Matrix was formed based on the data that were cleansed for the first study question, then the frequency calculation, finding related words, forming a word cloud, and drawing the graph were carried out. 
For the second study question, each word that was detected in each tweet was analyzed in sentimental terms by employing the RSentement and Bing Liu Glossaries; and the direction of the tweets was determined according to these two glossaries (very positive, positive, neutral, negative, very negative). Since there were no specific glossaries for sports sciences, two different glossaries were employed in the present study to increase the reliability of the findings on sentiment analysis. The R-Programming codes and their explanations that were employed for the analyses of the study questions are given below for the benefit of other researchers who would like to conduct studies on data analysis in social media.

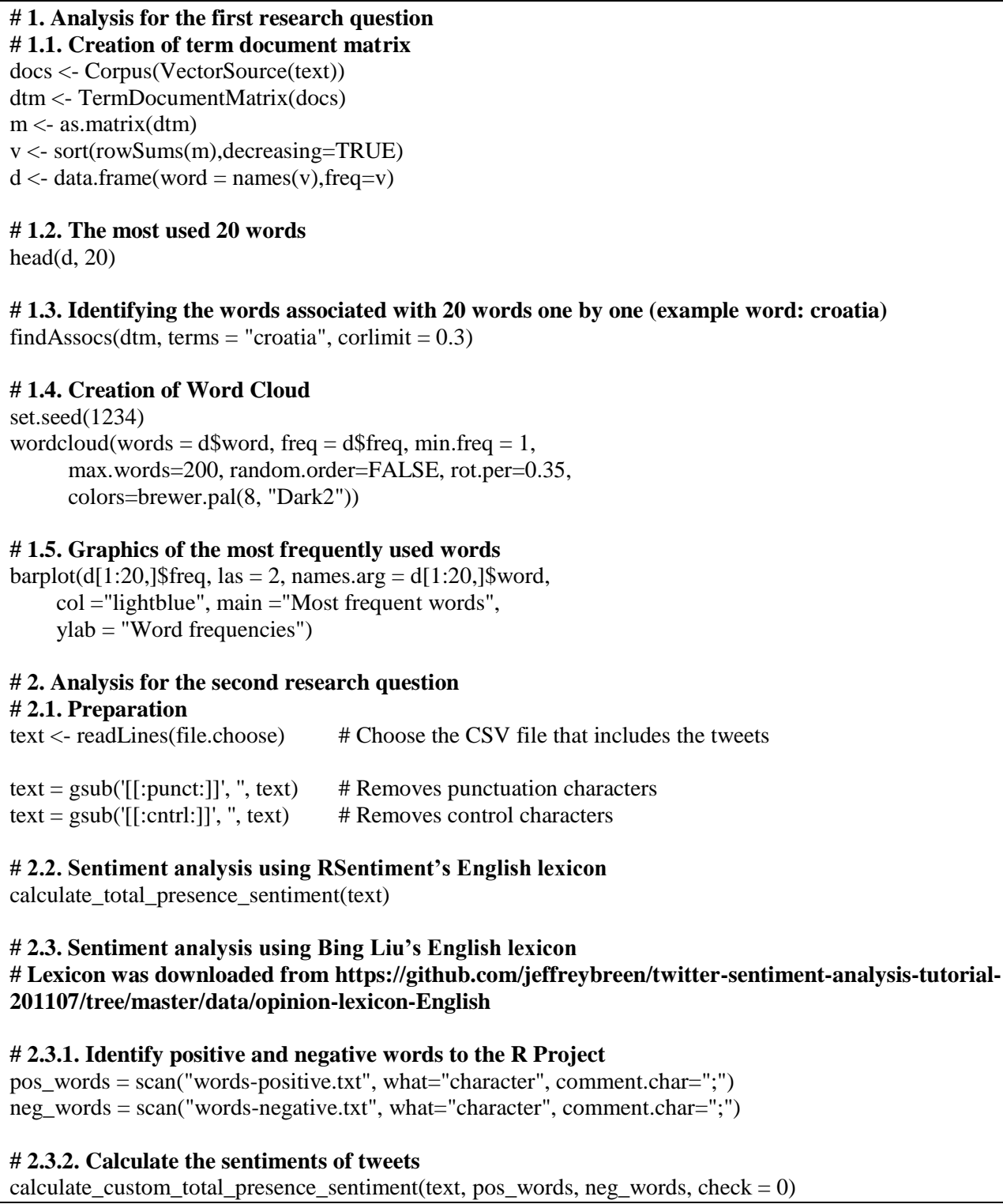




\section{FINDINGS}

The statements in the tweets for the 2018 World Cup final match that came to the forefront in the scope of the first study question, and the words that were related to these statements are provided. Then, a "word cloud" was formed for the 200 words that were used most frequently in these tweets. The statements and the words related to these expressions in the tweets that were posted regarding the 2018 World Cup final match are given in Table 1 below.

Table 1. The most used words in tweets and most frequently expressed used with these words

\begin{tabular}{|c|c|c|c|c|c|c|}
\hline \multirow{2}{*}{$\frac{\text { Word }}{\text { croatia }}$} & \multirow{2}{*}{$\frac{\text { Frequency }}{11071}$} & \multicolumn{5}{|c|}{ Used words together $(\%)$} \\
\hline & & attended (65) & grabarkitarovic (62) & kolinda (62) & hats $(61)$ & every $(60)$ \\
\hline france & 10920 & congrats $(62)$ & wowwhat (62) & game (60) & & \\
\hline kids & 10601 & reenacted $(82)$ & match (67) & & & \\
\hline match & 10235 & reenacted $(83)$ & kids (67) & & & \\
\hline game & 9945 & wowwhat (97) & congrats (94) & $\operatorname{good}(87)$ & france $(60)$ & \\
\hline reenacted & 7261 & match $(83)$ & kids $(82)$ & & & \\
\hline world & 6308 & $\operatorname{cup}(85)$ & & & & \\
\hline good & 5574 & wowwhat (89) & game (87) & $\begin{array}{l}\text { congrats } \\
(86)\end{array}$ & & \\
\hline cup & 5143 & world (85) & & & & \\
\hline congrats & 4841 & wowwhat (96) & game (94) & $\operatorname{good}(86)$ & france $(62)$ & \\
\hline work & 4719 & hard (97) & sides $(97)$ & & & \\
\hline president & 4561 & kolinda (74) & grabarkitarovic (71) & $\begin{array}{l}\text { attended } \\
(66)\end{array}$ & & \\
\hline hard & 4537 & sides $(100)$ & work (97) & & & \\
\hline sides & 4510 & hard (100) & work (97) & & & \\
\hline wowwhat & 4497 & game (97) & congrats $(96)$ & good (89) & france $(62)$ & \\
\hline \multirow[t]{2}{*}{ kylian } & 4176 & boots (84) & continuar (84) & dust (84) & $\begin{array}{l}\text { equaling } \\
(84)\end{array}$ & $\begin{array}{l}\text { igualar } \\
(84)\end{array}$ \\
\hline & & keeps (84) & records $(84)$ & may (83) & again (82) & like (71) \\
\hline \multirow[t]{2}{*}{ like } & 4078 & boots (85) & continuar $(85)$ & dust (85) & $\begin{array}{l}\text { equalling } \\
(85)\end{array}$ & $\begin{array}{l}\text { igualar } \\
(85)\end{array}$ \\
\hline & & keeps (85) & records $(85)$ & may (84) & again (83) & $\begin{array}{l}\text { kylian } \\
(71)\end{array}$ \\
\hline amp & 3835 & recreated $(86)$ & perfect (85) & $\begin{array}{l}\text { beautiful } \\
(84)\end{array}$ & & \\
\hline \multirow[t]{2}{*}{ again } & 3158 & boots (97) & continuar (97) & dust (97) & $\begin{array}{l}\text { equalling } \\
\text { (97) }\end{array}$ & $\begin{array}{l}\text { igualar } \\
\text { (97) }\end{array}$ \\
\hline & & keeps (97) & records (97) & like (83) & kylian (82) & \\
\hline beautiful & 3126 & recreated (97) & perfect (96) & $\operatorname{amp}(84)$ & & \\
\hline
\end{tabular}

When Table 1 is examined, it is seen that the statements about the 2018 World Cup Final Match are listed as: "Croatia", "France", "Kids", "Match", "Game", "Reenacted", "World", "Good", "Cup", "Congrats", "Work", "President", "Hard", "Sides", "Wowwhat", "Kylian”, "Like”, "Amp", "Again", and "Beautiful". Following the determination of the 20 statements that came to the forefront in the Twitter posts, it was determined which words they were most commonly used with together with over $60 \%$ frequency. In this respect, it was seen that the word "Croatia", which came to the forefront, was used together with the words "attended", "kolinda" and "grabarkitarovic". Another word, which came to the forefront was "France", which was used with the words "congrats", "game" and "wowwhat".

A "word cloud" consisted of the 200 words most commonly used in the tweets about the 2018 World Cup final match is given to consider the words from a wider viewpoint (Figure 2). 


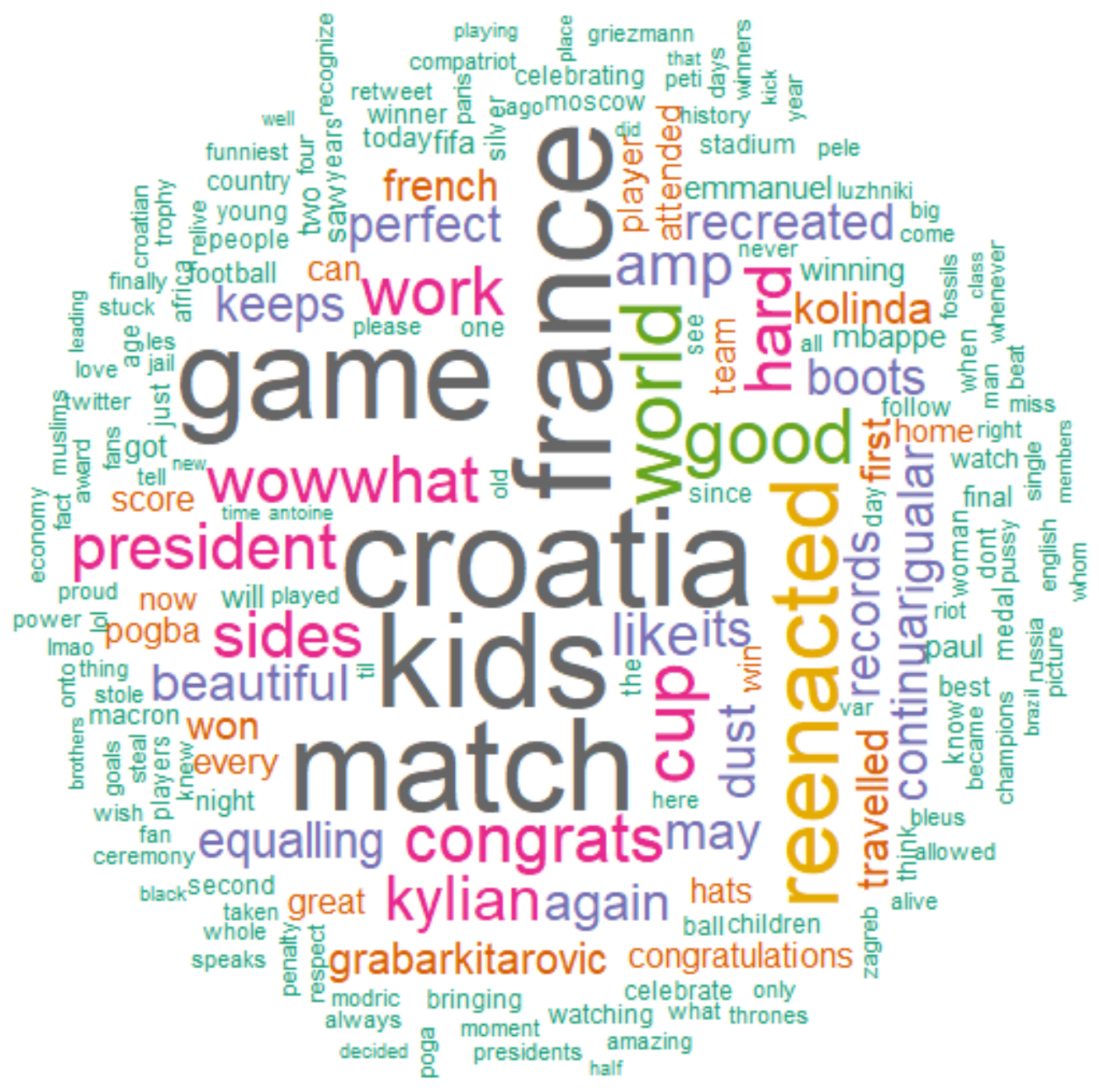

Figure 2. The "word cloud" that was formed for the 200 words that were most commonly used

As it may be understood from the "word cloud", it is seen that the words that represent the unifying power of football like "equaling", "perfect", "muslims", "bringing", "celebrate", "woman", "won", "brothers", "alive", "winner" were used in the posts.

In the scope of the second study question, a Sentiment Analysis was conducted in order to determine the sentimental tendencies of Twitter posts of the fans about the final match. Two different sentiment analysis glossaries (i.e. RSentement and Bing Liu) were employed for the purpose of determining the sentimental distribution of the tweets. The graph that shows the sentimental distribution of the tweets according to the RSentimens English Lexicon and Bing Liu Sentiment Lexicon is given below in Figure 3. 


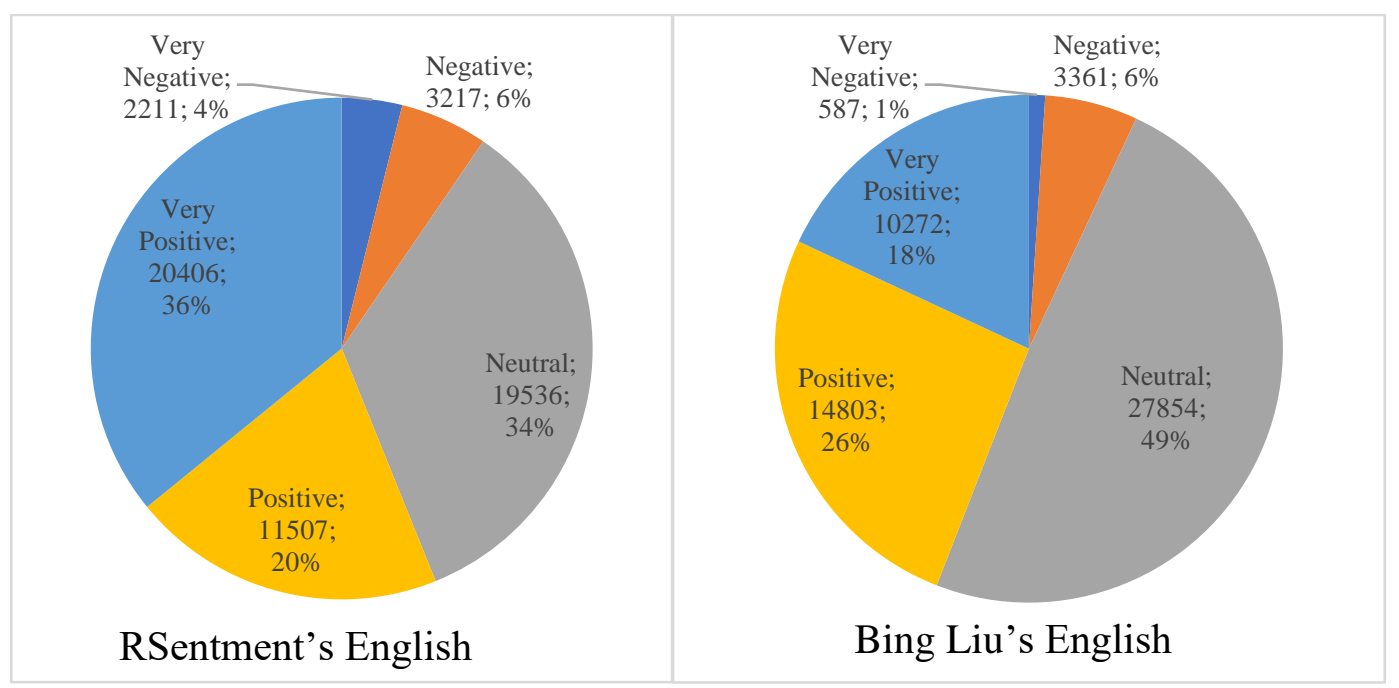

Figure 3. The sentimental distribution of tweets

When Figure 3 is examined it is seen that the word counts in Twitter shares according to the results of the analysis made with the RSentement Lexicon were; very negative $2211(4 \%)$, negative 3217 (6\%), neutral 19,536 (34\%), positive 11,507 (20\%) and very positive 20,406 (36\%). The word counts in Twitter posts according to the results of the analysis made with the Bing Liu Lexicon were; very negative 587 (1\%), negative 3361 (6\%), neutral 27,854 (49\%), positive 14,803 (26\%) and very positive 10,272 (18\%). As a result of the Sentiment Analysis that was carried out with RSentiment Lexicon, it was determined that the positive tweet rate was $56 \%$, and the negative tweet rate was $10 \%$. As a result of the Sentiment Analysis carried out with the Bing Liu Sentiment Lexicon, the rate of positive tweets was $44 \%$, and the negative tweet rate was 7\%. For this reason, it is understood that the rate of the positive tweets is higher at a significant level than the rate of the negative tweets according to both glossaries. However, according to the analysis results obtained with the RSentiment Lexicon, the rate of the Neutral tweets is $34 \%$, and $49 \%$ according to the analysis results obtained with the Bing Liu Sentiment Lexicon.

\section{DISCUSSION and CONCLUSION}

Since fans can express themselves in a comfortable manner in great sports events such as the World Cup, their sentimental reactions can be measured (Lucas et al., 2017). Based on this viewpoint, the purpose of the present study was to determine the statements of the fans in their tweets about the 2018 world cup final match, the words related to these statements, and the emotional tendencies in Twitter posts.

As the first step, the statements about the world cup final match in Twitter shares were determined in the scope of the first study question. In this respect, the statements "Croatia", "France", "kids", "match" and "game" came to the forefront in the tweets. Unlike statements of violent and hatred sometimes seen on football fields, the fact that the expressions in Twitter posts about the World Cup final match are positive attracts attention and is exciting. When the statements used were examined with a closer look, it is possible to claim that Twitter posts have positive statements including "Congrats", "Beautiful" and "Good". At this point, it is understood that the competition in the World Cup is different from club football; and nations seem to be supporting their teams in a gentle manner. It may also be claimed that fans who 
come from different religions, races or nationalities and speak different languages may well be uniting around the beauty of football in terms of fair play. Because sports -especially footballis a universal activity field that reduces the differences between cultures, improves international relations and contributes to world peace (Üstünel \& Alkurt, 2015).

Following the determination of the statements that came to the forefront in Twitter posts, the words that were used most frequently were determined. In this respect, it was determined that the word "Croatia", which came to the forefront, was used together with the words "attended", "kolinda" and "grabarkitarovic". It was also understood that another word, "France", which was used most frequently, was used together with the words "congrats", "game" and "wowwhat". It may be claimed that using the word "France" especially with the word "congrats" was due to the fact that it completed the tournament as the champion and had the world cup. It was also determined that the word "Croatia" was used in an intense manner together with the name of the political head of Croatia (Kolinda Grabar-Kitarovic). This can be explained in two ways. Firstly, the president of Croatia supported the Croatian national team throughout the World Cup, and was in the tribunes; and secondly, the relationship between football and politics showed itself in this World Cup specifically with Croatia.

Ince (2016), who examined the football-politics relationship, reported that governments adopted being within sports, especially in football, as a policy, and underlined that there is a close relationship between politicians and sports. Goig (2017), who analyzed the relationship between football and politics on a club basis with the fans of Barcelona, Atletico Madrid and Real Madrid in Spain, reported that the ideologies that were represented by the clubs overlapped with the political viewpoints of the fans. For this reason, the word "Croatia" being used together with the name of a head of state may be accepted as an indicator of the fact that football and politics are in very close contact.

For the purpose of considering the words that came to the forefront in the scope of the study, a "word cloud" that had 200 words was prepared. According to this "word cloud", it may be claimed that the words "equaling", "perfect", "muslims", "bringing", "celebrate" and "woman", which represent the peaceful and unifying power of football, were used. As a matter of fact, Afacan et al. (2017) pointed out that football, which was a popular sports branch, had a unifying and integrative structure. However, unlike this positive finding, it is observed that the studies reported in the literature examining the relationship between fans and football, were generally shaped around violence and hooliganism (Newson et al., 2018; Raspaud \& Bastos, 2013; Stott et al., 2008; Sekulic et al., 2015; Spaaij, 2008; Wakefield \& Wann, 2006). The fact that the findings of the present study is different from the findings reported in the literature may be explained with the difference in the viewpoints of the fans of the World Cup event.

In the scope of the second study question, the sentimental distributions of the Tweets that were posted by the fans on the final match were determined. For this purpose, the RSentiment English Lexicon and the Bing Liu English Lexicon were employed in Sentiment Analysis. The results of the Sentiment Analysis carried out with both dictionaries showed that the rate of positive tweets about to the final match was much higher than negative tweets. However, in a study conducted on the 2014 World Cup for Sentiment Analysis by Yu \& Wang (2015), it was concluded that the sentimental tendencies of the fans were negative in their Twitter posts when their team lost the game. However, it was concluded in another Sentiment Analysis study on 
the 2014 Olympic Games in Sochi, that the emotional tendencies of the supporters who followed the matches were positive in their Twitter posts (Krilenko \& Stepchenkova, 2017). For this reason, it may be said that the findings of the current study both overlapped and did not overlap with the literature. This situation may be interpreted as the aggressive attitude among the fans in club-level competitions does not exist at the national team level, such as in the 2018 World Cup.

Again, according to the results of the analysis that were made with the RSentiment Lexicon, it was seen that the rate of the neutral tweets was $34 \%$, and $49 \%$ according to the analysis made with the Bing Liu Sentiment Lexicon. According to the results of the analysis made with both glossaries, it may be claimed that the fans' neutrality in terms of sentiments was caused by the fact that final match was followed by the supporters of countries other than France and Croatia; and that they were able to remain neutral.

In this study, the statements of the fans that came to the forefront about the 2018 World Cup final match, the words that were related with these statements, and the emotional tendencies of Twitter posts were determined. In this respect, when the 56,877 tweets that were posted about the World Cup final match were analyzed, it was determined that:

- $\quad$ all of the statements and the words that were used together with these statements were positive,

- $\quad$ according to the "word cloud" that was prepared in the context of the study, it was determined that the words that were used on Twitter posts were positive in general,

- the rate of positive tweets were much more than the rate of negative tweets,

- the perception in which the competition at a national level in the World Cup and the competition among clubs differentiated in a positive way.

In future studies, it may be recommended that a glossary be formed for sentiment analysis in specific areas, such as sports sciences, and methods, e.g. machine learning, may be employed to analyze tweets that are written in more than one language.

Conflict of Interest: There is no conflict of interest.

Researchers' Contribution Rate Statement: The entire research process was carried out by the author.

\section{Research Ethics}

In the scope of the protection of human and animal rights, the Journal of Sport Sciences Researches adopts the exact convenience principle of national and international ethical rules and principles. In this context, the principles of the journal and general scientific ethical rules were followed during the research process. 


\section{REFERENCES}

Afacan, E., Onağ, Z., Demiran, D. \& Çobanoğlu, G. (2017). The reasons of violence in football and the ways to prevent them according to Professional football players views: The match between Tarsus İdman Yurdu Erkutspor and Yeni Salihlispor. International Journal of Social Science Research, 6(2), 124-141.

Aldayel, H. \& Azmi, A. M. (2016). Arabic tweets sentiment analysis - a hybrid scheme. Journal of Information Science, 42(6), 782-797. https://doi.org/10.1177/0165551515610513

Baudad, N., Faizi, R., Thami, R. \& Chibeb, R. (2017). Sentiment analysis in Arabic: A review of the literature. Ain Shams Engineering Journal, 9(4), 2479-2490. https://doi.org/10.1016/j.asej.2017.04.007

Ceron, A., Curini, L., Iacus, S. M. \& Porro, G. (2014). Every tweet counts? How sentiment analysis of social media can improve our knowledge of citizens' political preferences with an application to Italy and France. New Media \& Society, 16(2), 340-358. https://doi.org/10.1177/1461444813480466

Deiner, M. S., Fathy, C., Kim, J., Niemeyer, K., Ramirez, D., Ackley, S. F. \& Porco, T. C., (2017). Facebook and Twitter vaccine sentiment in response to measles outbreaks. Health Informatics Journal. https://doi.org/10.1177/1460458217740723

Fişek, K. (1998). Spor yönetimi (1. Baskl). Ankara: Bağırgan Yayınevi.

Goig, R. L. (2017). Football and politics in Spain: An empiricial analysis of the social base of the main football clubs. Journal of Iberian And Latin American Literary and Cultural Studies, 1(4), 79-100.

Himelboim, I., Sweetser, K. D., Tinkham, S. F., Cameron, K., Danelo, M. \& West, K. (2016). Valence-based homophily on Twitter: Network analysis of emotions and political talk in the 2012 presidential election. New Media \& Society, 18(7), 1382-1400. https://doi.org/10.1177/1461444814555096

İnce, M. (2016). Spor ile siyasetin ilişkisi üzerine bir analiz; Sporu siyasete alet etmek. Karabük Üniversitesi Sosyal Bilimler Enstitüsü Dergisi, 6(2), 456-464.

Ji, Q. \& Raney, A. A. (2014). Morally judging entertainment: A case study of live tweeting during downton abbey. Media Psychology, 18(2), 221-242. https://doi.org/10.1080/15213269.2014.956939

Kaynar, O., Yıldız, M., Görmez, Y. \& Albayrak, A. (2016). Sentiment Analysis with Machine Learning Techniques. Paper presented International Artificial Intelligence and Data Processing Sysmposium, September 28-30, 2018, Malatya, Turkey.

Khoo, C. S. \& Johnkhan, S. B. (2018). Lexicon-based sentiment analysis: Comparative evaluation of six sentiment lexicons. Journal of Information Science, 44(4), 491-511. https://doi.org/10.1177/0165551517703514

Kim, E. H., Jeong, Y. K., Kim, Y., Kang, K. Y. \& Song, M. (2016). Topic-based content and sentiment analysis of Ebola virus on Twitter and in the news. Journal of Information Science, 42(6), 763-781. https://doi.org/10.1177/0165551515608733

Kreiss, D. (2016). Seizing the moment: The presidential campaigns' use of Twitter during the 2012 electoral cycle. New Media \& Society, 18(8) 1473-1490. https://doi.org/10.1177/1461444814562445

Krilenko, A. P. \& Stepchenkova, S. O. (2017). Sochi 2014 Olympics a twitter: Perspective of hosts and guests. Tourism Management, 63(2017), 54-65. https://doi.org/10.1016/j.tourman.2017.06.007

Liu, B. (2012). Sentiment analysis and opinion mining (1. Edt.). Williston: Morgan \& Claypool Publishers. 
Lucas, G. M., Gratch, J., Malandrakis, N., Szablowski, E., Fessler, E. \& Nichols, J. (2017). GOAALLL! Using sentiment in the World cup to explore theories. Image and Vision Computing, 65(2017), 58-65. https://doi.org/10.1016/j.imavis.2017.01.006

Mackey, T., Kalyanam, J., Klugman, J., Kuzmenko, E. \& Gupta, R. (2018). Solution to detect, classify, and report 1llicit online marketing and sales of controlled substances via Twitter: using machine learning and web forensics to combat digital opioid access. Journal of Medical Internet Research, 20(4), e10029.

Mostafa, M. M. (2018). Clustering halal food consumers: A Twitter sentiment analysis. International Journal of Market Research, 61(3), 320-337. https://doi.org/10.1177/1470785318771451

Newson, M., Bortolini, T., Buhrmester, M., Da Silva, S. R., Da Aquino, J. N. Q. \& Whitehouse, H. (2018). Brazil's football worriors: Social bonding and inter-group violence. Evolution and Human Behavior, 39(2018), 675-683. https://doi.org/10.1016/j.evolhumbehav.2018.06.010

Öztürk, N. \& Ayvaz, S. (2017). Sentiment analysis on twitter: A text mining approach to the Syrian refugee crisis. Telematics and Informatics, 35(1), 136-147.

Pandey, A. C., Rajpoot, D. S. \& Saraswat, M. (2017). Twitter sentiment analysis using hybrid cuckoo search. Information Processing $\quad$ and https://doi.org/10.1016/j.ipm.2017.02.004

Pang, B. \& Lee, L. (2008). Opinion mining and sentiment analysis. Foundations and Trends in Information Retrieval, 2(1), 1-135.

Raney A.A. (2006). Why we watch and enjoy mediated sports. In: AA Raney \& J Bryant (Eds), Handbook of Sports and Media. New York: Lawrence Erlbaum Associates, pp 313-329.

Raspaud, M. \& Bastos, F. (2013). Torcedores de futebol: Violence and public policies in Brazil before the 2014 FIFA world cup. Sport in Society, Culture Commerce Media Politics, 16(2), 192-204. https://doi.org/10.1080/17430437.2013.776251

Sekulic, M., Kühl, S., Connert, T., Krastl, G. \& Filippi, A. (2015). Dental and jaw injuries sustained by hooligans. Dental Traumatology, 31(6), 477-481. 10.1111/edt.12205.

Souza, A., Figueredo, M., Cacho, N., Araújo, D. \& Prolo, C. A. (2016). Using big data and real-time analytics to support smart city initiatives. IFAC-PapersOnLine, 49(30), 257-262.

Spaaij, R. (2008). Men like us, boys like them: Violence, masculinity, and collective 1dentity in football hooliganism. Journal of Sport and Social Issues, 32(4), 369-392. https://doi.org/10.1177/0193723508324082

Stott, C., Adang, O., Livingstone, A. \& Schreiber, M. (2008). Tackling football hooliganism: A quantitative study of public order policing and crowd psychology. Psychology Public Policy and Law, 14(2), 115-141. http://dx.doi.org/10.1037/a0013419

Üstünel, R. \& Alkurt, Z. (2015). Futbolda şiddet ve düzensizliğin önlenmesi için 6222 sayılı yasanın getirdiği yeni bir uygulama: Elektronik bilet ve yaşanan sorunlar. Science Journal of Turkish Military Academy, 25(2), 141-175.

Wakefield, K. L. \& Wann, D. L. (2006). An examination of dysfunctional sport fans: Method of classification and relationships with problem behaviors. Journal of Leisure Research, 38(2), 168-186. DOI:10.1080/00222216.2006.11950074 
Wang, X. (2015). Using attitude functions self-efficacy and norms to predict attitudes and intentions to use mobile devices to access social media during sporting event attendance. Mobile Media and Communication, 3, 75-90. https://doi.org/10.1177/2050157914548932

Workewych, A. M., Muzzi, M. C., Jing, R., Zhang, S., Topolovec-Vranic, J.\& Cusimano, M. D. (2017). Twitter and traumatic brain injury: A content and sentiment analysis of tweets pertaining to sport-related brain injury. SAGE Open Medicine, 5, 1-11. https://doi.org/10.1177/2050312117720057

Yu, Y. \& Wang, X. (2015). World Cup 2014 in Twitter world: A big data analysis of sentiments in U.S. sports fans' tweets. Computer in Human Behavior, 48(2015), 392-400. https://doi.org/10.1016/j.chb.2015.01.075

Yu, Y., Duan, W. \& Cao, Q. (2013). The impact of social and conventional media on firm equity value: A sentiment analysis approach. Decision Support System, 55(4), 919-926. https://doi.org/10.1016/j.dss.2012.12.028

Zeng, B. \& Gerritsen, R. (2014). What do we know about social median tourism? A review. Tourism Management Perspective, 10, 27-36. https://doi.org/10.1016/j.tmp.2014.01.001

Except where otherwise noted, this paper is licensed under a Creative Commons Attribution 4.0 International license. 